\title{
Hate crimes in India
}

\section{Mohsin Alam Bhat ${ }^{1}$}

Published online: 4 August 2020

(c) O.P. Jindal Global University (JGU) 2020

Violence driven by sectarian hostility is back on the centre stage of India's public discourse. Since 2015, numerous incidents of hate violence have dramatically unfolded on the pages of both old and new media. While we still do not have any official numbers, data drawn from media sources indicates a considerable spike in incidents of individuals being targeted on the ground of their identity. ${ }^{1}$ Many of these incidents have involved mobs attacking members of caste and religious minorities, often in the context of cow protection or inter-faith relationships. ${ }^{2}$

India has had a long and tortuous history of sectarian mass violence. ${ }^{3}$ The country was born in the throngs of the tragic Partition in 1947 that led to more than two million deaths. ${ }^{4}$ Since then, there have been hundreds of incidents of what in India are often described as 'communal riots'. ${ }^{5}$ Sectarian mass violence is intimately related in terms of causes and effects — to political ideologies and ambitions. ${ }^{6}$ Violence has

\footnotetext{
${ }^{1}$ See Alison Saldanha and Karthik Madhavapeddi, 'Our New Hate-Crime Database: $76 \%$ of Victims Over 10 Years Minorities; 90\% Attacks Reported Since 2014' (Fact Checker, 30 October 2018). https:// archive.factchecker.in/our-new-hate-crime-database-76-of-victims-over-10-years-minorities-90-attacksreported-since-2014/. Accessed 17 July 2020.

2 Annie Gowen, 'A Muslim and a Hindu Thought They Could be a Couple. Then Came the 'Love Jihad' Hit List.' (The Washington Post, 26 April 2018). https://www.washingtonpost.com/world/asia_pacific/amuslim-and-a-hindu-thought-they-could-be-a-couple-then-came-the-love-jihad-hit-list/2018/04/26/25701 0be-2d1b-11e8-8dc9-3b51e028b845_story.html. Accessed 17 July 2020; Rahul Bhatia, 'The Year of Love Jihad in India' (The New Yorker, 31 December 2017). https://www.newyorker.com/culture/2017-inreview/the-year-of-love-jihad-in-india. Accessed 17 July 2020.

${ }^{3}$ Asghar Ali Engineer (ed), Communal Riots in Post-Independence India (2nd edn, Universities Press 1997); Ashutosh Varshney, Ethnic Conflict and Civic Life: Hindus and Muslims in India (Yale University Press 2002).

${ }^{4}$ Gyanendra Pandey, Remembering Partition: Violence, Nationalism and History in India (Cambridge University Press 2001); Ian Talbot and Gurharpal Singh, The Partition of India (Cambridge University Press 2009).

5 Steven I Wilkinson, 'Riots' (2009) 12 Annual Review of Political Science 329.

${ }^{6}$ Zoya Khaliq Hasan, 'Communalism and Communal Violence in India' (1982) 10(2) Social Scientist 25 .
}

M Mohsin Alam Bhat-Associate Professor.

M Mohsin Alam Bhat

mabhat@jgu.edu.in

1 Jindal Global Law School, O.P. Jindal Global University, Sonipat, India 
often accompanied sectarian mobilisation in the context of elections. ${ }^{7}$ The most striking problem throughout this history has been state complicity in violence, and impunity of state and non-state actors. ${ }^{8}$

While there is a need for more research, contemporary incidents of hate violence appear to follow these patterns. Most of the reported incidents have involved targeting of individuals rather than mass violence. But they continue to fit into, and often serve, a political ecosystem. ${ }^{9}$ Incidents of violence have often preceded and followed political hate speech. ${ }^{10}$ And as is the case with sectarian mass violence, the report on legal accountability here remains dismal. ${ }^{11}$

This special issue seeks to make three contributions. First, it reckons with the contemporary. What are the historical antecedents of contemporary hate violence in India? In what ways is the present moment a continuation from the past? What new challenges for the law does it pose? Second, it seeks to advance the conversation around hate violence by taking legal categories seriously. What categories are best attuned to capture the personal and social harm of violence? How should we best interpret these legal categories to advance the ends of justice? Third, the issue takes the role of institutions seriously. How should we evaluate the role of criminal justice institutions in addressing - or maintaining — impunity? What are the best institutional strategies to address violence?

\section{Situating the contemporary}

This issue self-consciously situates itself in the current moment. On 1 April 2017, a mob of self-styled gau rakshaks (cow protectors) attacked and killed Pehlu Khan only a few kilometres from Delhi. ${ }^{12}$ Pehlu, a 55-year-old dairy farmer, was

\footnotetext{
${ }^{7}$ Paul Brass, The Production of Hindu-Muslim Violence in Contemporary India (University of Washington Press 2011); Steven I Wilkinson, Votes and Violence: Electoral Competition and Ethnic Riots in India (Cambridge University Press 2004).

${ }^{8}$ See Surabhi Chopra and Prita Jha (eds), On Their Watch: Mass Violence and State Apathy in India, Examining the Record (Three Essays Collective 2014).

${ }^{9}$ See Nilanjan Mukhopadhyay, 'Lynching and Trolling: Why Political Parties Can't Absolve Themselves of Responsibility' (The Economic Times, 8 July 2018). https://economictimes.indiatimes.com/blogs/ et-commentary/lynching-and-trolling-why-political-parties-cant-absolve-themselves-of-responsibility/. Accessed 17 July 2020; Shoaib Daniyal, 'The Modi Years: What has Fuelled Rising Mob Violence in India?' (Scroll.in, 23 February 2019). https://scroll.in/article/912533/the-modi-years-what-has-fuelledrising-mob-violence-in-india. Accessed 17 July 2020.

${ }^{10}$ Nimisha Jaiswal, Sreenivasan Jain, and Manas Pratap Singh, 'Under Modi Government, VIP Hate Speech Skyrockets - By 500\%' (NDTV, 19 April 2018). https://www.ndtv.com/india-news/under-naren dra-modi-government-vip-hate-speech-skyrockets-by-500-1838925. Accessed 17 July 2020.

${ }^{11}$ KTS Tulsi, 'Fear of Law has Evaporated as Cases of Lynching Have Become Regular and Brazen' (Outlook, 23 December 2019). https://www.outlookindia.com/magazine/story/india-news-opinion-fearof-law-has-evaporated-as-cases-of-lynching-have-become-regular-and-brazen/302503. Accessed 17 July 2020.

12 Abhishek Dey, “'He Said He Was Hindu, They Let Him Go”: How One Man Escaped an Attack by Cow Vigilantes in Alwar' (Scroll.in, 6 April 2017). https://scroll.in/article/833800/\%20he-said-he-washindu-they-let-him-go-how-one-man-escaped-an-attack-by-cow-vigilantes-in-\%20alwar. Accessed 5 April 2020.
} 
transporting cows he had recently purchased from a cattle fair across the border in the State of Rajasthan. The video of the gruesome act that was soon circulating online generated both outrage and alarm. This, unfortunately, was not an isolated incident. Over the next many months, a series of violent incidents — with Dalit and Muslim victims - came to dominate the public discourse. In July 2018, the former Chief Justice of the Supreme Court, Deepak Misra, warned against India turning into a 'mobocracy'. 13

These incidents of vigilantism and mob lynching were a reminder of the deep social cleavages in our society. They also soon exposed the limitations in the criminal justice system. Commentators and activists noted the failure of the police to rein in the perpetrators. They also noted the tremendous costs of this violence for the victims and survivors, as well as for the social fabric.

While this special issue was being finalised, Delhi was on fire. From December 2019, there were unprecedented protests against the Citizenship Amendment Act, 2019. ${ }^{14}$ The legislation introduced a religious test for citizenship for a country that many have always seen to be founded on secularism. ${ }^{15}$ The inspiring mobilisation adopted the constitutional language of equality and inclusion in the face of tremendous political opposition. Just as the protests were dealing with the impact of COVID-19, shocking violence broke out in Delhi on 23 February 2020. The violence, initially directed at the protestors, spread like wildfire, resulting in more than 50 casualties and hundreds of displaced citizens.

The sectarian violence was a reminder that this special issue must foreground its immediate context even as it sought to intervene academically. This context made the intervention urgent and significant. The interviews with Harsh Mander and Teesta Setalvad - two of the foremost activists in the field - keep this issue grounded in the concrete realities of violence, impunity, and accountability. Both Mander and Setalvad chart the histories of sectarian violence in India - from the Partition violence, the various episodes of mass communal violence, to the recent spate of more localised incidents of lynching. They draw from their extensive experience of legal activism to explore the entrenched institutional problems that have inhibited legal accountability. They also offer the political causes and stakes of battling hate violence. Significantly, their experiments with legal interventions offer important resources to scholars and researchers interested in constructing social solidarities and litigation strategies.

Nikhil Roshan's photo-essay further grounds this special issue. It highlights both the context as well as the ethical stakes involved. Through images and text, Roshan explores the horrors of the recent Delhi violence. He presents a vivid portrayal of what we may often miss in our study of hate violence. We do see the loss of life.

\footnotetext{
13 Tehseen S. Poonawalla v Union of India \& Others (2018) 9 SCC 501.

14 Human Rights Watch, "Shoot the Traitors": Discrimination Against Muslims under India's New Citizenship Policy (April 2020).

15 Niraja Gopal Jayal, 'Citizenship Amendment Act: 'Principle of Discrimination Based on Faith will be Difficult to Limit'’ (The Indian Express, 24 December 2019). https://indianexpress.com/article/expla ined/indian-constitution-citizenship-amendment-act-modi-govt-6181761/. Accessed 17 July 2020.
} 
But we may fail to see how everyday poverty and segregation enable violence. His contribution reminds us that overt violence breaks out from intractable — and often invisible - marginalisation.

\section{Framing hate crime}

The political and legal category that is conventionally used to describe sectarian violence in India is 'communal riot'. As Setalvad points out in this issue, the use of the word 'riot' potentially mischaracterises the nature of the violence, which is often targeted against minorities and accompanied by state complicity. She argues that the category of 'pogrom' is better suited to describe the nature and impact of sectarian violence in the Indian context.

The Supreme Court's July 2018 order, which acknowledged the harms of hate violence, laid down a series of guidelines to counter it. ${ }^{16}$ The Court framed its intervention in terms of the category of 'lynching'. ${ }^{17}$ In their contribution to the issue, Bhat, Bajaj, and Kumar point out how - despite the Court's extensive guidelines - police personnel have often operated with an interpretation of the category that runs counter to the stated objectives of the judicial order.

This discussion illuminates the value of paying close attention to the words we use to describe violence within and outside legal discourse. Joanna Perry's contribution to the issue is a strong expression of this keen attention on how legal categories visibilise violence, create spaces of institutional redress, and travel transnationally. Perry argues in favour of adopting the hate crime framework in India, which in her view invites institutions to focus on protection for marginalised groups facing violence, rather than treating them as the problem. The core of her contribution offers an institutional and contextual account of how the hate crime concept has travelled into local national contexts. She notes that this can be best understood as a vernacularisation of the concept: national state and non-state actors adopt the concept creatively by often formulating 'partner concepts' that suit the local contexts. She thus advocates creative, strategic, and hybrid ways of battling hate crime by evolving local techniques, definitions, and institutional modes. She argues that 'vigilantism' can be such a partner concept in India, which can incorporate the normative and institutional goals of the hate crime concept while being responsive to the specific challenges in the country.

While Perry focuses on vigilantism as a potential partner concept in India, Vandita Khanna's contribution develops the concept of 'targeted violence'. Using the Delhi High Court's judgment ${ }^{18}$ in the Hashimpura massacre case as a springboard, she develops the normative contours of targeted violence. Specifically, she shows the concept's potential for making the autonomy and dignity harms of violence legally legible.

\footnotetext{
16 Tehseen S. Poonawalla v Union of India \& Others (n 13).

17 ibid.

18 Zulfikar Nasir \& Others $v$ State of Uttar Pradesh \& Others 2018 SCC Online Del 12153.
} 
This focus on legal categories — rather novel in the Indian context — can generate a more searching academic conversation about how various manifestations of hate crime are connected. There is now an important field of scholarship on castebased violence or atrocities. How is the category of caste atrocities conceptually, legally, and normatively related to that of hate crime based on other identities like religion, race, ethnicity, disability, or sexual orientation? Does thinking of them within the rubric of hate crime enhance our understanding of violence and generate more compelling solidarities? Or will we lose out on nuance and specificity? We hope the special issue generates this dialogue.

\section{Legal institutions}

The third theme of this special issue is the promise and limitations of legal institutions. In her contribution, Perry quotes legal anthropologist Sally Engle Merry on one of the most profound challenges of law. While the state is often the major violator of human rights, Merry writes, 'ironically it is also the agent for carrying out human rights reforms.' 19

The nuances of this central dilemma are apparent in the interview with Mander. He describes the long legal battle for legal justice in cases of sectarian violence. The debate on the Prevention of Communal and Targeted Violence (Access to Justice and Reparations) Bill, 2011 is of particular relevance. As he notes, the specific challenge in India has been not to proliferate criminal law, but to strengthen institutional accountability. His account perhaps reveals the need for a constant acknowledgment — on the part of advocates, lawyers, and activists — of the law's entrenched limitations to counter violence.

This is also the core of Bhat, Bajaj, and Kumar's contribution. They provide a sobering account of the Supreme Court's celebrated judgment against mob lynching. ${ }^{20}$ Their detailed interviews with police officials, and the account of one police investigation in a lynching case, show that the fate of court orders and criminal legislation remains precariously subject to the quotidian exercise of police discretion. This exercise is shaped by and channels entrenched police culture and institutional bias. The conversation about legal reform, thus, must also integrate the systemic questions of prejudice, power, and democracy.

Publisher's Note Springer Nature remains neutral with regard to jurisdictional claims in published maps and institutional affiliations.

\footnotetext{
${ }^{19}$ Sally Engle Merry, Human Rights and Gender Violence: Translating International Law into Local Justice (University of Chicago Press 2009) 5.

${ }^{20}$ Tehseen S. Poonawalla $v$ Union of India \& Others (n 13).
} 